\title{
Molecular genetic analysis of human folate receptors in neural tube defects
}

\author{
Sandra G Heil ${ }^{1}$, Nathalie MJ van der Put ${ }^{1}$, Frans JM Trijbels ${ }^{1}$, Fons JM G abreëls ${ }^{2}$ and \\ Henk J Blom ${ }^{1}$
}

${ }^{1} \mathrm{D}$ epartment of Paediatrics and ${ }^{2} \mathrm{D}$ epartment of Child N eurology, U niversity H ospital Nijmegen, The N etherlands

\begin{abstract}
Neural tube defects (NTDs) are the most common congenital malformations and are considered to have a multifactorial origin, having both genetic and environmental components. Periconceptional folate administration reduces the recurrence and occurrence risk by 70-100\% . R ecently we discovered the first genetic risk factors for NT D s: the 677 C $\rightarrow$ T and the $1298 \mathrm{~A} \rightarrow \mathrm{C}$ mutations in the methylenetetrahydrofolate reductase gene explaining at the most $35-50 \%$ of the protective effect of folate. In this study we further explored the genetic component of NTD s by analysing the coding region, including the intron-exon boundaries and signal sequences of the folate receptor genes by SSC $P$ analysis. A mong 39 patients with spina bifida (SB ), 47 mothers with a child with SB, and 10 controls, no polymorphism was present in the folate receptor alpha $(F R-\alpha)$ gene or in the folate receptor beta (FR- $\beta$ ) gene.
\end{abstract}

Keywords: folate receptor alpha; folate receptor beta; molecular genetic analysis; neural tube defects

\section{Introduction}

Spina bifida (SB) and anencephaly are congenital malformations due to incomplete closure of the neural tube. Neural tube defects (NTD s) are considered to be multifactorial in origin, ie a combination of genetic and nutritional factors. ${ }^{1}$ Periconceptional folate administration reduces both the occurrence and recurrence risk of NTD s by $70-100 \%$. $^{2,3}$

In our previous studies elevated plasma homocysteine concentrations in combination with slightly lowered plasma folate levels were observed in mothers with a NTD child. ${ }^{4,5} \mathrm{~N}$ ext, we discovered two mutations ( $677 \mathrm{C} \rightarrow \mathrm{T}$ and $1298 \mathrm{~A} \rightarrow \mathrm{C}$ ) in the methylenetetrahydrofolate reductase (MTHFR) gene, which are con-

Correspondence: Henk J Blom, Department of Paediatrics, University Hospital Nijmegen, PO Box 9101, 6500 HB N ijmegen, The N etherlands. Tel: + 3124 3613469; Fax: +31 24 3618900; E-mail: H.Blom@ckslkn.azn.nl

R eceived 8 July 1998; revised 2 N ovember 1998; accepted 18 N ovember 1998 sidered genetic risk factors for NTD. ${ }^{4,6}$ These mutations in the M THFR gene can explain at the most $35-50 \%$ of the protective effect of folate. Therefore, other defects in the folate metabolism such as defective folate receptors could be involved in the aetiology of NTDs.

Folate receptors (FR) are involved in the binding and transport of folate in the form of 5-methyltetrahydrofolate (5-M ETHF). D efective function of the folate receptors could result in decreased transport of 5-M ETH F, resulting in lowered intracellular concentrations of the different active folates. It has already been shown in mice that dysfunctional folate receptors result in lower intracellular folate concentrations. ${ }^{7}$ In the murine system, folate binding protein 1 (FB P-7) shows a higher affinity for 5-MeTHF compared with folate binding protein 2 (F B P-2) ${ }^{8,9} \mathrm{M}$ ice models heterozygous for the FBP-1 null allele or homozygous for the FBP-2 null allele show decreased circulating folic acid concentrations compared with wild-type mice. ${ }^{7} \mathrm{M}$ ice homozygous for the FBP-1 null allele fail to close the neural 
tube. The FBP-2 null homozygous show no abnormalities and develop in normal adult animals. ${ }^{7}$

In humans, four isoforms $\left(\alpha, \beta, \gamma\right.$ and $\left.\gamma^{\prime}\right)$ of the folate receptors with a tissue specific expression are known. ${ }^{10}$ $F R-\alpha$ and $F R-\beta$, the analogous forms of the murine FBP-1 and FBP-2, are attached to the plasma membrane by a glycosyl-phosphatidylinositol (GPI) anchor, whilst the FR $-\gamma$ and $F R-\gamma^{\prime}$ are secretory proteins. ${ }^{11}$

In this study we analysed by SSCP ${ }^{12}$ the coding region including the intron-exon boundaries and the signal sequences of the human FR- $\alpha$ and FR $-\beta$ genes in SB children, their mothers and controls for possible pathologic mutations.

\section{Materials and Methods}

\section{Patient Material}

In collaboration with the Child N eurology D epartment of our hospital, blood was drawn from 39SB patients (mean age $19.9 \pm 4.1$ years) , 47 mothers (mean age $39.1 \pm 5.5$ years) with a child with SB, and 10 controls (mean age $36.6 \pm 5.0$ years). The controls were healthy hospital employees. The local ethics committee approved this study.

\section{Mutation Analysis}

G enomic DNA was isolated from whole blood as described by Miller et al. ${ }^{13}$ For SSCP analysis we designed specific primers based on the genomic sequence of the $F R-\alpha$ and FR $-\beta$ genes (Table 1 ). The exons of both genes are small (about $200 \mathrm{bp}$ ), therefore the primers were designed on the intronic sequences resulting in overlapping polymerase chain reaction (PCR) products of about $250 \mathrm{bp}$, including the intron-exon boundaries. The final exons of both genes were split into two fragments because of the size of these exons ( $>350 \mathrm{bp}$ ). D ue to a FR - $\alpha$ pseudogene with a homology in coding sequence of $66 \%$ the primers were designed in such a way, that only the FR- $\alpha$ gene was amplified, which was confirmed by sequencing of PCR products on an A BI 377 automated sequencer using the DyeD eoxy terminator cycle sequencing kit according to the instructions of the manufacturer (Perkin Elmer, Nieuwerkerk a/d Y ssel, The $\mathrm{N}$ etherlands).

PCR was carried out in a total volume of $25 \mu l$ on an 0 mniG ene thermocycler (Biozym, L andgraaf, The Netherlands), containing $50 \mathrm{ng}$ of forward and reverse primers, $200 \mu \mathrm{m}$ dNTPs, $10 \mathrm{~mm}$ Tris- $\mathrm{H} \mathrm{Cl}$ buffer (pH 8.3), $1.0 \mathrm{~mm} \mathrm{M} \mathrm{gCl}$, 0.5 unit Taq polymerase (all from Life Technologies, B reda, The N etherlands). PCR parameters were as follows: $92^{\circ} \mathrm{C}$ for $120 \mathrm{~s}$ (initial denaturation) followed by 35 cycles of $92^{\circ} \mathrm{C}$ for $60 \mathrm{~s}$ (denaturation), $56-66^{\circ} \mathrm{C}$ for $90 \mathrm{~s}$ (annealing) and $72^{\circ} \mathrm{C}$ for $90 \mathrm{~s}$ (extension) followed by a final extension step of 7 minutes at $72^{\circ} \mathrm{C}$.

PCR -SSCP was carried out in the presence of $55 \mathrm{kB} \mathrm{q} \mathrm{\alpha -}{ }^{32} \mathrm{P}$ dCTP (A mersham, Pharmacia Biotech, R oosendaal, The Netherlands). The PCR products were loaded on MDE gels (Sanvertech, H eerhugowaard, The $\mathrm{N}$ etherlands) in combination with Tris-B orate buffer ( $54 \mathrm{~mm}$ Tris, $53 \mathrm{~mm}$ boric acid and $1.2 \mathrm{~mm}$ EDTA, pH 8.3) as described previously. ${ }^{14}$ PCR fragments with different banding patterns were sequenced according to the above method.

R ecently, a $586 \mathrm{~T} \rightarrow \mathrm{C}$ substitution in the $\mathrm{FR}-\alpha$ gene was described ${ }^{15}$ which we examined in our study group by $P C R$ with primers 7a-for and 7a-rev (Table 1). A fter PCR, $15 \mu$ l was

Table 1 Primer sequences of FR - $\alpha$ and FR $-\beta$

\begin{tabular}{|c|c|c|c|}
\hline Primer & $\begin{array}{l}\text { Primer-sequences } \\
5^{\prime} \rightarrow 3^{\prime}\end{array}$ & $\begin{array}{l}\text { A nnealing temp. } \\
(\stackrel{\circ}{ } \mathrm{C})\end{array}$ & $\begin{array}{l}\text { Fragment size } \\
\text { (bp) }\end{array}$ \\
\hline $\begin{array}{l}\text { FR }-\boldsymbol{\alpha} \\
4 \text { for } \\
4 \text { rev } \\
5 \text { for } \\
5 \text { rev } \\
6 \text { for } \\
6 \text { rev } \\
7 \text { a for } \\
7 \text { a rev } \\
7 b \text { for } \\
7 b \text { rev }\end{array}$ & $\begin{array}{l}\text { A ACTTAAGGCCCCACCTCCG } \\
\text { GATCACCCCCTGGCCCAC } \\
\text { TCTGTCTTCCCCCATCCAGTG } \\
\text { GGTCTTGTACCTGCAGGAAGCC } \\
\text { CTGAGTTGCTGGGATTCTTGAA } \\
\text { CTCCACTTCCAAATCCCTCCA } \\
\text { GCTGGCAGACCTCAAGATAGTTCC } \\
\text { GGCCCAGCCCCACTCATG } \\
\text { GCCGCTGCATCCAGATGTG } \\
\text { TCAGAGGCCCGACCATGG }\end{array}$ & $\begin{array}{l}56 \\
58 \\
56 \\
66 \\
58\end{array}$ & $\begin{array}{l}251 \\
237 \\
229 \\
281 \\
247\end{array}$ \\
\hline $\begin{array}{l}\text { F } R \text { - } \boldsymbol{\beta} \\
2 \text { for } \\
2 \text { rev } \\
3 \text { for } \\
3 \text { rev } \\
4 \text { for } \\
4 \text { rev } \\
5 \text { a for } \\
5 \text { a rev } \\
5 \text { b for } \\
5 \text { b rev }\end{array}$ & $\begin{array}{l}\text { TTCCCCTCAGGACTTGGTTTC } \\
\text { TTAGCAGAGGCACACTCCA GC } \\
\text { CTTAGTCCTGTGTCTTCCCCACC } \\
\text { AGTCTGCTGGGGTGGGTG } \\
\text { AGTCACTTCAAGGCGATGGC } \\
\text { CCTCAATCTCCTTTTCCTAACCC } \\
\text { GGGCTGAAAGTCTGTGTCCACC } \\
\text { TGGCTGCAGCATAGAACCTCG } \\
\text { GTTTGATTCAGCCCAGGGC } \\
\text { GCTTAAGGGGCTGTCATTTTG }\end{array}$ & $\begin{array}{l}56 \\
56 \\
54 \\
58 \\
56\end{array}$ & $\begin{array}{l}232 \\
267 \\
248 \\
242 \\
233\end{array}$ \\
\hline
\end{tabular}


digested with $\mathrm{Hphl}$ restriction enzyme, which cuts the obtained $242 \mathrm{bp}$ fragment into two fragments of $117 \mathrm{bp}$ and $125 \mathrm{bp}$ if the mutation is present. A s a positive control, $\lambda \mathrm{DNA}$ was also digested using the same protocol.

\section{Results}

The genomic DNA of the $F R-\alpha$ and $F R-\beta$ genes was analysed by SSCP. No crucial shifts could be detected. Some slightly different banding patterns were observed in both genes but sequencing revealed no polymorphism. Furthermore, a $586 \mathrm{~T} \rightarrow \mathrm{C}$ substitution in exon 7 of FR - $\alpha$ published by others ${ }^{15}$ was investigated. This substitution was not present in our SB patients or in our mothers with a SB child.

\section{Discussion}

D efective folate receptor function could play an important role in the aetiology of NTDs. ${ }^{7}$ We analysed the human FR- $\alpha$ and FR - $\beta$ genes using SSCP analysis by overlapping primer sets encompassing the complete coding region. Because the genomic structure was known we located the primers in the introns, which enabled us to screen also the intron-exon boundaries. $M$ utations in these regions can produce alternative splicing events. We also investigated the FR $-\alpha$ and $F R-\beta$ signal sequences, which are required for attachment of the folate receptors to the plasma membrane.

We studied all exons of the FR - $\alpha$ and FR $-\beta$ genes and did not find any important abnormalities in the coding region (including the intron-exon boundaries and signal sequences) of $F R-\alpha$ and $F R-\beta$ in SB patients and their mothers. Thus far we have no evidence for an involvement of the FR genes in the aetiology of NTD s in humans. During our investigation Barber et al also reported on mutation analysis of the FR- $\alpha$ gene. ${ }^{9}$ They screened 33 SB patients and almost 1400 controls for mutations in exons 4, 6 and 7 by SSCP analysis. Exons 6 and 7 were entirely sequenced in 50SB patients. Furthermore, exons 4, 5, 6 and 7 of 219 individuals (SB patients and controls) were subjected to dideoxy fingerprinting (ddF). No polymorphism was detected in any of the four exons examined, which is confirmed by our study (we adapted their exon numbering according to $G$ enbank accession number $U 20391$ for $F R-\alpha$ and number $X 69516$ for $F R-\beta)$.
We studied all FR - $\alpha$ and FR- $\beta$ exons in one study group, contrary to $B$ arber et al who used different study groups for each exon and did not study the FR $-\beta$ gene. ${ }^{9}$ Furthermore, we screened in addition to the SB patients, mothers with SB offspring, since it is not known whether genetic factors present in mothers or in the foetus have a predominant role in the closure of the neural tube.

Possible involvement of $F R-\alpha$ and $F R-\beta$ in the aetiology of SB cannot be completely excluded, because variations in the $5^{\prime}$ and $3^{\prime}$ UTR or the promotor region resulting in unstable or reduced levels of mRNA have not yet been studied. Theoretically, FR genes could play an important role in the aetiology of NTD s. ${ }^{7,9} \mathrm{H}$ owever, we did not find any abnormalities in the coding region (including the intron-exon boundaries and signal sequences) of these genes. Variations at nucleotide level seem to be very rare. Possibly, folate receptors play such an important part in the development of the embryo, that abnormalities in the genes coding for these receptors could be lethal. This hypothesis is confirmed by studies on mice; mice homozygous for the FB P-1 null allele failed to close their neural tube and were not able to develop into live-born mice. ${ }^{7}$

The recently discovered mutations in the MTHFR gene prove that mutations in genes of the folate dependent homocysteine metabolism can be risk factors for SB. ${ }^{4,6}$ Because these MTHFR mutations can explain only a part of the preventive effect of folate, other genetic variations in the folate dependent homocysteine metabolism are still expected to be present in SB patients and/or their mothers.

\section{Acknowledgements}

This study was supported by grant 93-1104 and 98-0109 from the Prinses Beatrix Fonds, The Netherlands, and by grant B M H 4-CT 95-0505 from the E U Commission D emonstration Project.

\section{References}

1 Copp A J, B rook FA, E stibeiro JP, Shum A SW, Cockroft DL: The embryonic development of mammalian neural tube defects. Progr Neurobiol 1990; 35: 363-403.

2 MRC Vitamin Study Research Group: Prevention of neural tube defects results of the Medical Research Council vitamin study. L ancet 1991; 338: 131-137. 
3 Czeizel A E, D udas I: Prevention of the first occurrence of neural-tube defects by periconceptional vitamin supplementation. N Engl J Med 1992; 327: 1832-1835.

4 van der Put NMJ, Steegers-Theunissen R PM, Frosst P et al: $M$ utated methylenetetrahydrofolate reductase as a risk factor for spina bifida. L ancet 1995; 346: 1070-1071.

5 Steegers-Theunissen R PM , B oers G J H, Trijbels J M F et al: $M$ aternal hyperhomocysteinemia: a risk factor for neuraltube defects? M etabolism 1994; 43: 1475-1480.

6 van der Put NMJ, Gabreels F, Stevens EMB et al: A second common mutation in the methylenetetrahydrofolate reductase gene: $\mathrm{A} n$ additional risk factor for neural tube defects? A m J H um G enet 1998; 62: 1044-1051.

7 Finnell R H, G reer KA, Barber R C, Piedrahita J A : N eural tube and craniofacial defects with special emphasis on folate pathway genes. Crit Rev Oral Biol Med 1998; 9: 38-53.

8 Brigle KE, Westin EH, Houghton MT, Goldman D: Characterization of two CDNA S encoding folate-binding proteins from L 1210 murine leukemia cells. J Biol Chem 1991; 266: 17243-17249.

9 Barber RC, Shaw GM, Lammer EJ et al: Lack of association between mutations in the folate receptor- $\alpha$ gene and spina bifida. Am J Med Genet 1998; 76: 310-317.
10 Shen $F$, R oss J F, Wang X, R atnam M : Identification of a novel folate receptor, a truncated receptor, and receptor type B in hemapoietic cells: cDNA cloning, expression, immunoreactivity, and tissue specificity. Biochemistry 1994; 33: 1209-1215.

11 A nthony A C: Folate receptors. A nnu Rev Nutr 1996; 16: 501-521.

12 O rita $M$, I wahana $H$, K anazawa $H$, H ayashi $K$, Sekiya $T$ : Detection of polymorphisms of human DNA by gelelectrophoresis as single-strand conformation polymorphisms. Proc Natl A cad Sci 1989; 86: 2766-2770.

13 Miller SA, Dykes DD, Polesky HF: A simple salting out procedure for extracting DNA from human nucleated cells. Nucleic A cids Res 1988; 16: 1215.

$14 \mathrm{Hol}$ FA, van der Put NMJ, Geurds MP et al: Molecular genetic analysis of the human trifunctional enzyme MTHFD (methylenetetrahydrofolate dehydrogenasemethenyltetrahydrofolate cyclohydrolase-formyltetrahydrofolate synthetase) in the etiology of neural tube defects. Clin G enet 1998; 53: 119-125.

15 Capra V, D eM arco P, Moroni A et al: Mutations of folic acid receptor alpha in neural tube defects. Am J Hum Genet 1997; 61: A 149. 